\title{
Characteristics of the g/mS ribozyme suggest only structural roles for divalent metal ions
}

\author{
ADAM ROTH, ${ }^{1}$ ALI NAHVI, ${ }^{2,3}$ MARK LEE, ${ }^{2}$ INBAL JONA, ${ }^{1}$ and RONALD R. BREAKER ${ }^{1,2}$ \\ ${ }^{1}$ Howard Hughes Medical Institute, Department of Molecular, Cellular and Developmental Biology and ${ }^{2}$ Department of \\ Molecular Biophysics and Biochemistry, Yale University, New Haven, Connecticut 06520, USA
}

\begin{abstract}
The $g / m S$ ribozyme is a riboswitch class that occurs in certain Gram-positive bacteria, where it resides within mRNAs encoding glucosamine 6-phosphate synthase. Members of this self-cleaving ribozyme class rapidly catalyze RNA transesterification upon binding GlcN6P, and genetic evidence suggests that this cleavage event is important for down-regulating GlmS protein expression. In this report, we present a refined secondary structure model of the $g / m S$ ribozyme and determine the importance of a conserved pseudoknot structure for optimal ribozyme function. Analyses of deletion constructs demonstrate that the pseudoknot, together with other structural elements, permits the ribozyme to achieve maximum rate constants for RNA cleavage at physiologically relevant $\mathrm{Mg}^{2+}$ concentrations. In addition, we show that substantial rate enhancements are supported by an exchange-inert cobalt (III) complex and by molar concentrations of monovalent ions. Our findings indicate that the $\mathrm{g} / \mathrm{mS}$ ribozyme forms a complex structure to employ catalytic strategies that do not require the direct participation of divalent metal ions.
\end{abstract}

Keywords: ribozyme; riboswitch; glmS; glucosamine 6-phosphate; metal ions; pseudoknot

\section{INTRODUCTION}

Riboswitches are structured RNA elements that most commonly reside within $5^{\prime}$ untranslated regions (UTRs) of bacterial mRNAs, where they control gene expression through direct binding interactions with small molecule ligands. A number of these RNA-based regulatory motifs have been identified that respond to compounds with fundamental roles in metabolism, including the amino acids lysine and glycine, the nucleobases guanine and adenine, and the coenzymes adenosylcobalamin, thiamine pyrophosphate, flavin mononucleotide, and S-adenosylmethionine (Mandal and Breaker 2004; Winkler 2005). Recently, we reported the discovery of a novel riboswitch class (Winkler et al. 2004) that represses gene expression in response to rising concentrations of GlcN6P, a sugar-phosphate compound that is a fundamental metabolic intermediate in the biosynthesis of bacterial cell walls.

${ }^{3}$ Present address: Howard Hughes Medical Institute, Department of Molecular Biology and Genetics, Johns Hopkins University School of Medicine, Baltimore, MD 21205, USA.

Reprint requests to: Ronald R. Breaker, Howard Hughes Medical Institute, Department of Molecular, Cellular and Developmental Biology, Yale University, P. O. Box 208103, New Haven, CT 06520-8103, USA; e-mail: ronald.breaker@yale.edu; fax: (203) 432-0753.

Article published online ahead of print. Article and publication date are at http://www.rnajournal.org/cgi/doi/10.1261/rna.2266506.
Riboswitches typically make use of two distinct functional domains to modulate gene expression in response to changing concentrations of their cognate metabolites. An aptamer domain mediates selective binding of the target compound, and structural changes brought about by binding induce an adjoining expression platform to exert control over gene expression (Soukup and Soukup 2004). The aptamer domain of a riboswitch is most easily identified because its role as a metabolite receptor demands a precise structural organization that is well conserved phylogenetically. In contrast, an individual aptamer class can be associated with different expression platforms that can vary widely in sequence and structure, but still control gene expression by one of several different mechanisms. Among bacteria, riboswitches most commonly exert gene control at the level of transcription termination or translation initiation, although the modular construction of riboswitches allows them to be adapted for participation in a variety of control mechanisms. The majority of riboswitches appear to function as allosteric RNA switches, wherein ligand binding to the aptamer domain causes structural and functional changes to occur distally within the expression platform.

The $g l m S$ riboswitch is unique because it controls gene expression by undergoing ligand-induced self-cleavage. Examples of self-cleaving $g \operatorname{lm} S$ ribozymes are present in the $5^{\prime}$ UTRs of glmS mRNAs in Bacillus subtilis and numerous other Gram- 
positive bacteria (Winkler et al. 2004). At high concentrations of GlcN6P (the metabolite product of the GlmS protein), the rate constant for self-cleavage by the ribozyme is accelerated at least 10-million-fold over the uncatalyzed rate constant for RNA transesterification ( $\mathrm{Li}$ and Breaker 1999). Experiments demonstrating a negative correlation between the levels of $g l m S$ RNA-driven reporter gene expression in vivo and ribozyme activity in vitro have established the $g l m S$ ribozyme as a type of riboswitch whose mechanism of gene regulation has an autocatalytic component (Winkler et al. 2004).

Despite its unique metabolite dependence, the $\mathrm{glmS}$ ribozyme has several characteristics in common with four other natural classes of self-cleaving RNAs. The hammerhead, hairpin, hepatitis delta virus (HDV), and Neurospora Varkud satellite (VS) ribozymes each employ an internal phosphoester transfer mechanism for RNA scission, in which a $2^{\prime}$-hydroxyl group at the cleavage site is activated for nucleophilic attack on the adjacent phosphorus center (Fedor and Williamson 2005). The glmS ribozyme uses an identical phosphoester transfer mechanism to yield products with $5^{\prime}$ hydroxyl and $2^{\prime}, 3^{\prime}$-cyclic phosphate termini (Winkler et al. 2004). Another feature the $\operatorname{glm} S$ ribozyme shares with some of the previously identified self-cleaving RNAs is relaxed metal ion specificity (Dahm and Uhlenbeck 1991; Chowrira et al. 1993; Collins and Olive 1993; Suh et al. 1993), as a variety of divalent metal ions can substitute for $\mathrm{Mg}^{2+}$ in promoting GlcN6P-dependent self-cleavage (Winkler et al. 2004). Interestingly, several of the small RNA enzymes initially reported to exhibit relaxed metal ion specificities have subsequently been shown to employ catalytic strategies that do not require the direct participation of divalent metal ions (Hampel and Cowan 1997; Nesbitt et al. 1997; Young et al. 1997; Murray et al. 1998), raising the prospect that the $g \operatorname{lm} S$ ribozyme might be similarly devoid of an absolute requirement for divalent metals.

Approximately one-half of the $\mathrm{glmS}$ ribozyme secondary structure, composed of several phylogenetically conserved stems at the $3^{\prime}$ end (the P3/P4 domain), may be deleted without abrogating GlcN6P-responsive cleavage activity in vitro (Winkler et al. 2004). Similarly, certain small nucleolytic ribozymes have been reported to contain functionally or structurally conserved domains that are formally dispensable for catalysis, but that nonetheless are required for stabilization of the respective active structures under physiological conditions (Lilley 2003). These parallel observations prompt the question of whether the P3/P4 domain of glmS RNA might be serving an analogous purpose.

In this study, we investigate in greater detail the metal ion requirements of the glmS ribozyme. In addition, we demonstrate the existence of a phylogenetically conserved pseudoknot and evaluate whether the $\mathrm{P} 3 / \mathrm{P} 4$ subdomain in which it resides may be functionally analogous to the stabilizing domains identified in other nucleolytic ribozymes.

\section{RESULTS}

\section{Identification of an additional representative of the $g / m S$ motif}

Based on a phylogeny containing 19 sequences from mostly Gram-positive bacteria, a revised secondary structure model was assigned for the glmS ribozyme (Fig. 1). The modified consensus structure of this self-cleaving RNA contains a newly identified pairing element (P3a) in addition to the four stem-loop structures proposed in Barrick et al. (2004) (Fig. 2). Two of the stem-loop structures (P2 and P4) carry conserved sequences within internal loops, while most of the remaining primary sequence conservation occurs in the region between the cleavage site and $\mathrm{P} 1$, in the $\mathrm{P} 1-\mathrm{P} 2$ joining sequence (J1/2), and in loop 4 (L4). The 18 original members of the glmS ribozyme phylogeny were identified using both the BLISS database (Barrick et al. 2004), which assesses sequence similarity among intergenic regions from a collection of microbial genomes, and the SEQUENCESNIFFER program (J. Barrick and R.R. Breaker), which is similar to RNAMotif (Macke et al. 2001) and searches for specific motifs according to defined sequence and secondary structure parameters.

In the course of examining an expanded version of the BLISS database (Corbino et al. 2005), we encountered an additional $g \operatorname{lm} S$ RNA motif not noted in the earlier report. Interestingly, this sequence was identified not in a species of the Firmicutes (Bacillus/Clostridium group), where the majority of $g l m S$ motifs have been identified, but rather in association with the glmS gene from Deinococcus radiodurans, a species of the Deinococcus/Thermus group (Fig. 1). As a result, this newly identified representative expands the occurrence of the glmS motif to three bacterial lineages, including the previous report of one such motif in Fusobacteria (Fusobacterium nucleatum) (Barrick et al. 2004).

While the $g \operatorname{lm} S$ element from $D$. radiodurans largely conforms to the proposed secondary structure model, there are some subtle departures from the consensus. Among the predicted stems of the $g \operatorname{lm} S$ structural model, the strands depicted as comprising the P2a stem (blue highlights [interior pairing] in Fig. 1) are highly conserved in primary sequence and exhibit by far the least amount of covariation. The sequence of the $D$. radiodurans element in this region, although it has been threaded as shown to conform to this base-pairing arrangement, could also be slightly adjusted in register to align more closely with the conserved primary sequence in this region, but this would come at a significant cost to the potential for the depicted Watson-Crick pairing arrangement. Thus, while the current rendering depicts sequences in this local area as a stem, there is the possibility that the proposed P2a stem sequences adopt an alternative structure, perhaps even one devoid of canonical base-pairing interactions.

Another deviation from the consensus exhibited by the $D$. radiodurans glmS motif is the loss of an otherwise absolutely 

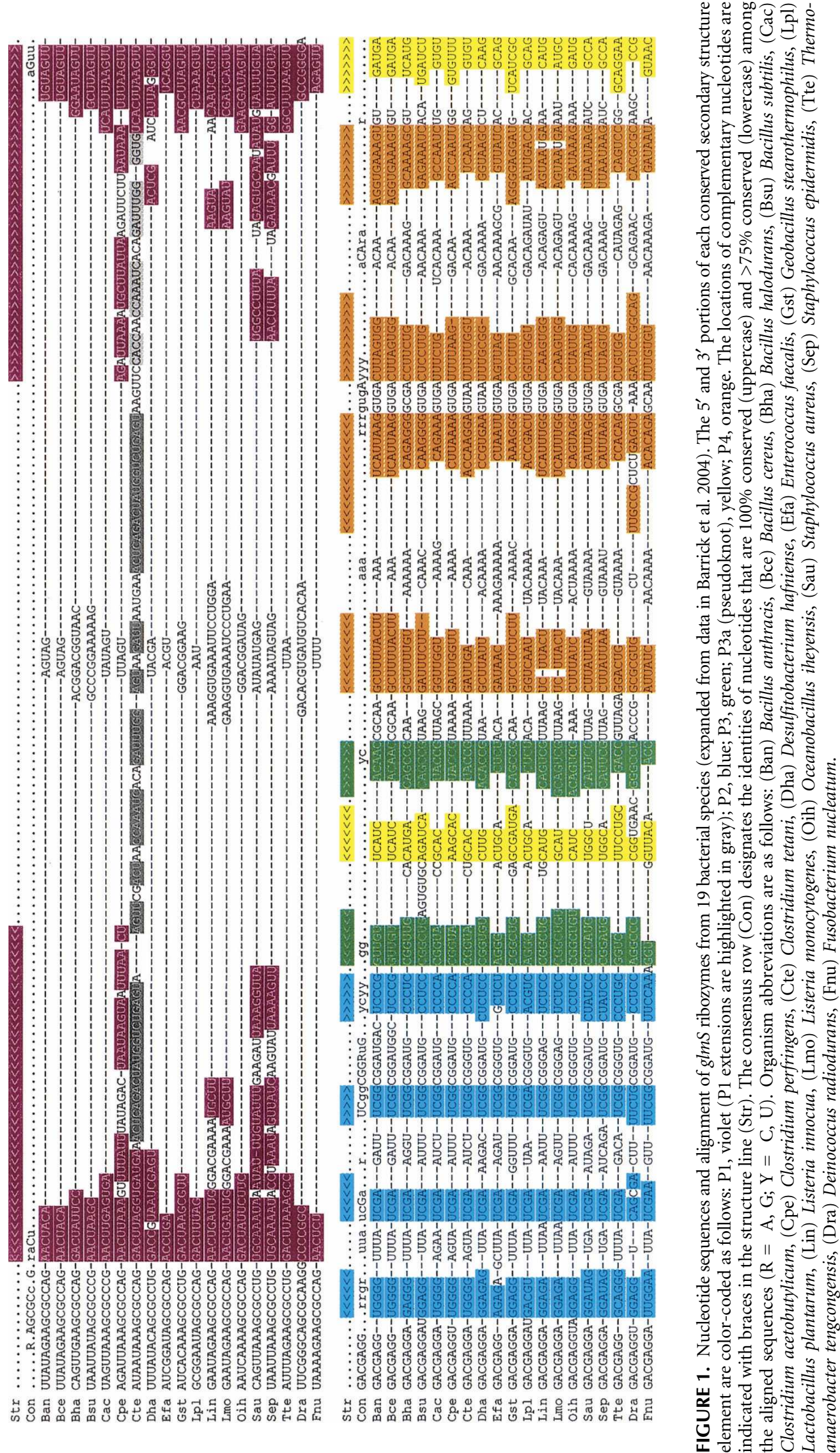


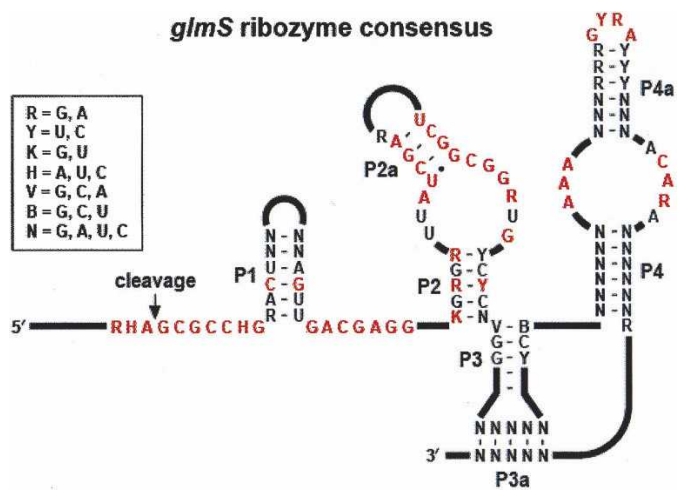

FIGURE 2. Consensus secondary structure for $g l m S$ ribozymes based on the revised sequence alignments in Figure 1. Nucleotides in red and in black are conserved in at least $\sim 95 \%(18 / 19)$ and $\sim 80 \%(15 / 19)$ of the representatives, respectively. Lines represent nonconserved sequences of variable length.

conserved adenosine triplet in the $\mathrm{P} 4$ stem, together with the apparent redistribution of unpaired sequences within this stem, resulting in a bulge and asymmetric internal loop. In addition, the nucleotides corresponding to $\mathrm{L} 4$ in the $D$. radiodurans glmS RNA fail to conform to the putative GNRA tetraloop sequence conserved in all other members of the phylogeny. Despite these deviations from the consensus, RNAs corresponding to the $g \operatorname{lm} S$ element from $D$. radiodurans exhibit accelerated rate constants for site-specific self-cleavage in response to GlcN6P (data not shown). Moreover, the ability of this newly identified $g l m S$ ribozyme species to discriminate against compounds related to GlcN6P is similar to that of representatives adhering more closely to the consensus.

\section{Expanding the conserved structure of the $\mathrm{g} / \mathrm{mS}$ ribozyme}

Upon further inspection of the sequence representatives, we have identified a phylogenetically conserved base-pairing arrangement (P3a) that forms a pseudoknot between nucleotides within L3 and nucleotides $3^{\prime}$ to the P4 stem (Figs. 1, 2). The pseudoknot ranges from 3 to $7 \mathrm{bp}$, and almost all of the nucleotides contained within L3 contribute to formation of the pseudoknot in most of the representatives examined. The number of L3 residues lacking a base-pairing partner appears typically to be limited to one or two, although sequences from two organisms (B. subtilis and D. radiodurans) suggest that additional nonduplex nucleotides may be accommodated within this loop. The length of the linker sequence between the P4 and the P3a stems (J4/3a) appears to be narrowly constrained to between 1 and $4 \mathrm{nt}$.

\section{The $g / m S$ ribozymes from $B$. subtilis and $B$. cereus display similar kinetic profiles}

We expect that each $g l m S$ ribozyme representative will exhibit similar biochemical and kinetic characteristics in order to ensure comparable responses to changing intracellular concentrations of GlcN6P. To examine this assumption, we chose to establish the performance characteristics of the $g \operatorname{lm} S$ ribozyme from Bacillus cereus, in part because this representative appears to have the lowest number of nonessential nucleotides residing within L1, L3, and the P4 internal bulge (Fig. 1). This reduced length might be advantageous for those who pursue future structural studies on $\mathrm{glmS}$ ribozymes.

A $5^{\prime 32} \mathrm{P}$-labeled B. cereus $201 \mathrm{glmS}$ RNA (corresponding to nucleotides -159 to +41 relative to the translation start site), whose predicted secondary structure is shown in Figure 3A, undergoes rapid self-cleavage in the presence of elevated concentrations of GlcN6P. The response to GlcN6P over a wide range of concentrations is similar to the profile observed previously with the glmS ribozyme from B. subtilis (Fig. 3B). Ribozymes from both organisms exhibit a nearly log-linear dependence on effector concentration over $\sim 2$ orders of magnitude and attain half-maximum rate enhancements of $\sim 1$ $\min ^{-1}$ in the presence of $200 \mu \mathrm{M}$ GlcN6P.

Under standard assay conditions, the B. subtilis and $B$. cereus $g \operatorname{lm} S$ ribozymes undergo self-cleavage in the absence of effector with rates of between $0.001 \mathrm{~min}^{-1}$ and $0.01 \mathrm{~min}^{-1}$ (corresponding to the minimum $k_{\text {obs }}$ values in Fig. 3B). While these rates are 2-3 orders of magnitude slower than those measured in the presence of saturating concentrations of GlcN6P, they nevertheless represent enhancements of as much as $10^{5}$-fold over the uncatalyzed rate of RNA strand cleavage. During the course of this study, we noticed (particularly when GlcN6P was absent) that $g l m S$ ribozyme incubations in solutions buffered with Tris- $\mathrm{HCl}$ (the chloride salt of protonated tris-(hydroxymethyl)-aminomethane) resulted in significantly more cleavage activity than in similar solutions containing other buffers. A series of reactions containing identical concentrations of HEPES (N-(2-hydroxyethyl)piperazine- $\mathrm{N}^{\prime}$-2-ethanesulfonic acid) and varying concentrations of Tris- $\mathrm{HCl}$ demonstrates this stimulatory effect (Fig. $3 \mathrm{~B}$, inset). The effect of Tris- $\mathrm{HCl}$ appears to be exerted through structural mimicry of the amine-containing portion of GlcN6P (McCarthy et al. 2005). Since the glmS ribozyme recognizes GlcN6P in a highly specific manner, its affinity for the chemically dissimilar Tris compound is likely to be quite poor. However, the presence of the Tris- $\mathrm{HCl}$ at millimolar concentrations presumably permits substantive binding of the buffer in the binding site for GlcN6P, where it acts as a functional substitute for the natural ligand.

Because assays monitoring the effect of GlcN6P concentration on cleavage activity were buffered with Tris- $\mathrm{HCl}$, rate measurements taken in the lower range of effector concentrations are likely to be artificially elevated. In order to learn the actual extent of effector-induced ribozyme activation, similar assays were repeated in solutions buffered with HEPES. A plot obtained with B. cereus 201 $g l m S$ under these modified conditions displays a similar maximum $k_{\text {obs. }}$. As expected, the minimum $k_{\text {obs }}$ value dropped to as low as $10^{-5} \mathrm{~min}^{-1}$, indicating that saturating 
A
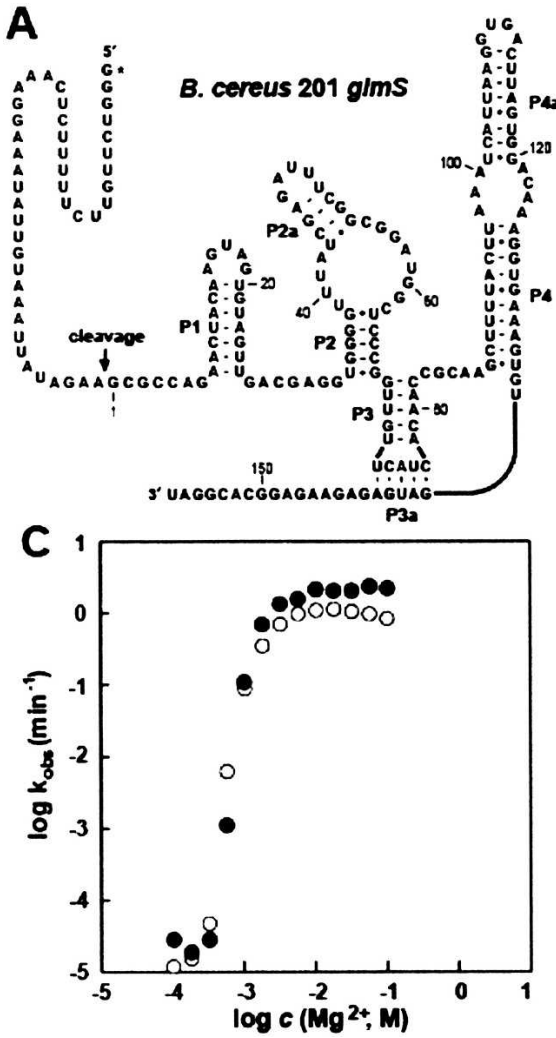

B
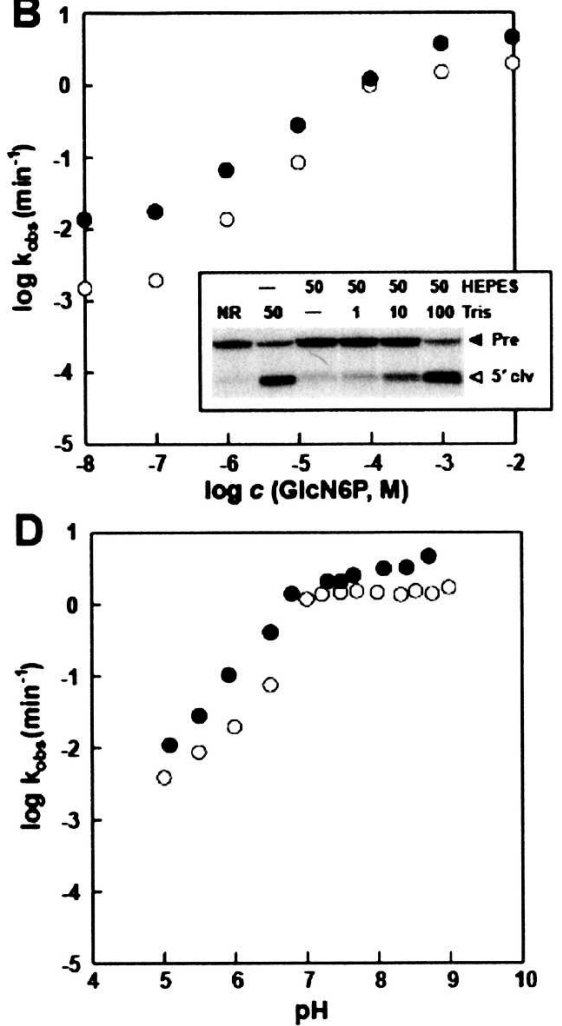

FIGURE 3. Biochemical analyses of glmS ribozymes from B. subtilis and B. cereus. (A) Secondary structure model of B. cereus $201 \mathrm{glmS}$ RNA. The G residue marked with an asterisk was introduced to improve the yield of transcription in vitro. (B) Effect of GlcN6P concentration on the rate of self-cleavage of the $g l m S$ ribozyme from B. cereus (filled circles). Data corresponding to the 246 $g l m S$ ribozyme from $B$. subtilis are shown for comparison (open circles). (Inset) Effect of Tris- $\mathrm{HCl}$ buffer on the rate of self-cleavage in the absence of GlcN6P. $5^{\prime 32} \mathrm{P}$-labeled B. cereus $201 \mathrm{glmS}$ RNA was incubated for $4 \mathrm{~h}$ in reactions buffered to $\mathrm{pH} 7.5$ with various concentrations of HEPES or Tris as indicated in mM. NR designates no reaction. Precursor and $5^{\prime}$ cleavage product bands are indicated. $(C, D)$ Effects of $\mathrm{MgCl}_{2}$ concentration $(c)$ and $\mathrm{pH}$ on rate constants under otherwise standard assay conditions. Reactions from $\mathrm{pH}$ 7.0-9.0 were buffered with Tris, and those below pH 7.0 were buffered with 2-[N-morpholino] ethanesulfonic acid (MES). Data corresponding to B. cereus and B. subtilis glmS ribozymes are represented as in $B$.

concentrations of GlcN6P stimulate the activity of this ribozyme by $\sim 100,000$-fold (data not shown).

Although the actual dynamic range of the $g \operatorname{lm} S$ ribozyme in vitro is much greater than that suggested previously (Winkler et al. 2004), it is unlikely that the full range of this effector-dependent response would be exploited in vivo. It seems doubtful whether the intracellular concentration of a critical metabolite like GlcN6P would fluctuate to such an extent, as it is presumably required to be maintained at relatively high concentrations due to its role in cell wall biosynthesis and remodeling. Moreover, because of the rapid turnover of bacterial mRNAs (Kushner 2002), the extended half-lives in vitro of uncleaved RNAs at low GlcN6P concentrations would not be biologically relevant.

We also compared the effects of additional biochemical parameters on cleavage kinetics. Similarly to the B. subtilis variant, the B. cereus $201 \mathrm{glmS}$ ribozyme exhibits a strong dependence on the concentration of $\mathrm{Mg}^{2+}$ under standard

assay conditions, approaching a rate maximum near physiological concentrations of this metal ion (Fig. 3C). The B. cereus ribozyme also behaves similarly in its response to $\mathrm{pH}$, displaying a log-linear rate enhancement with increasing basicity that becomes maximal near neutral $\mathrm{pH}$ (Fig. 3D). Collectively, these data demonstrate that the $g l m S$ ribozyme from B. cereus behaves similarly to the ribozyme from B. subtilis, as might be expected for genetic switches that perform identical roles in different organisms. Furthermore, these findings suggest that the fundamental characteristics of one representative might apply equally to other members of this ribozyme class.

\section{Metal dependence of the $g / m S$ ribozyme from $B$. cereus}

It was determined previously that a number of different divalent metal ions could support self-cleavage of the $g l m S$ ribozyme (Winkler et al. 2004). To establish quantitatively the degree to which certain other divalent cations could substitute for $\mathrm{Mg}^{2+}$, we examined the cleavage rates of $B$. cereus $201 \mathrm{glmS}$ over a range of $\mathrm{Mn}^{2+}$ and $\mathrm{Ca}^{2+}$ concentrations. The effects on the rate of increasing concentrations of each of these metal ions are quite similar to those observed with a series of $\mathrm{Mg}^{2+}$ concentrations, resulting in a sharply ascending profile that approaches a plateau in the low millimolar range (Fig. 4A). The ability of other divalent metal ions functionally to replace $\mathrm{Mg}^{2+}$ indicates a certain amount of promiscuity in the specificity of the corresponding binding sites. This is a characteristic that is shared by several of the other small self-cleaving ribozymes (Dahm and Uhlenbeck 1991; Chowrira et al. 1993; Collins and Olive 1993; Suh et al. 1993).

The relaxed divalent metal ion specificity observed in other catalytic RNAs may be readily explained in light of several recent reports that certain small catalytic RNAs, including the hairpin, the hammerhead, and the VS ribozymes, do not depend strictly on direct interactions with divalent metals but instead require only the presence of dense positive charge in the form of transition metal complexes, monovalent ions, or even organic polycations (Fedor 2002). To begin assessing whether a mechanism independent of divalent metals might also apply in the case of the $g l m S$ ribozyme, we tested the ability of $\mathrm{Co}\left(\mathrm{NH}_{3}\right)_{6}{ }^{3+}$, a structural mimic of hexahydrated $\mathrm{Mg}^{2+}$, to 

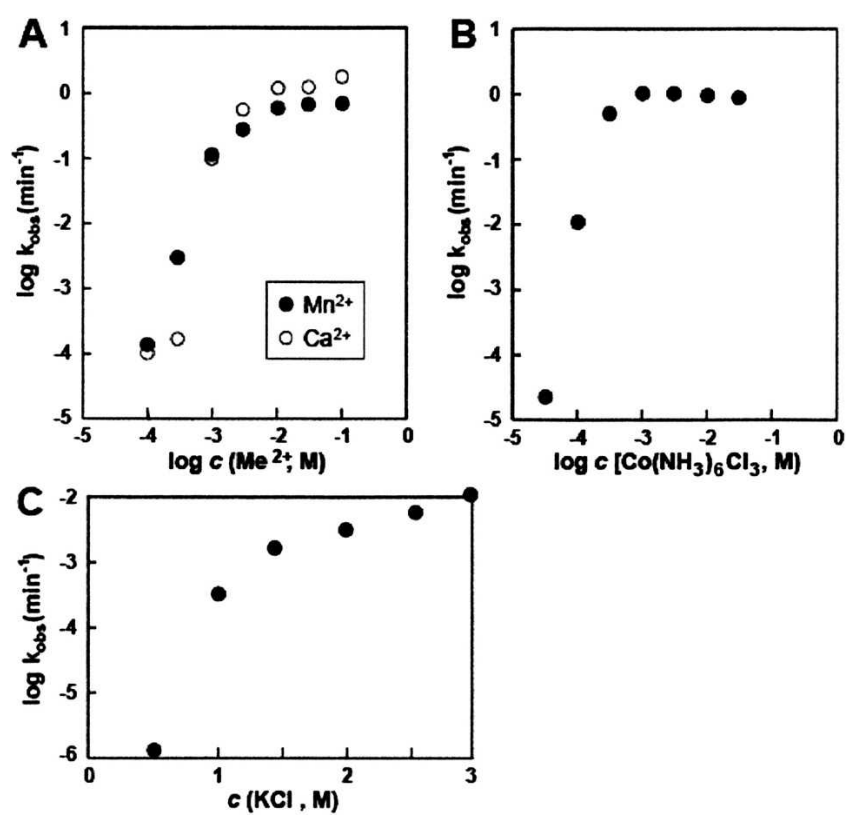

FIGURE 4. Cation requirements for self-cleavage of the B. cereus 201 $g l m S$ ribozyme. (A) Effect on the rate constant of substituting $\mathrm{Mg}^{2+}$ with varying concentrations of $\mathrm{Mn}^{2+}$ or $\mathrm{Ca}^{2+}$. (B) Effect on the rate constant of varying concentrations of $\mathrm{Co}\left(\mathrm{NH}_{3}\right)_{6} \mathrm{Cl}_{3}$. $(C)$ Cleavage activity in high concentrations of $\mathrm{KCl}$. Reactions in $B$ and in $C$ were performed in the absence of added divalent metal ions and supplemented with EDTA at concentrations of $2.5 \mathrm{mM}$ and $25 \mathrm{mM}$, respectively.

functionally replace divalent metal ions. Because $\mathrm{Co}^{3+}$ is inert, exchange of the inner sphere amine ligands is slow relative to the timescale of the cleavage reaction, resulting in a mode of association of $\mathrm{Co}\left(\mathrm{NH}_{3}\right)_{6}{ }^{3+}$ with RNA that can be mediated only through electrostatic and outer sphere interactions (Jou and Cowan 1991; Cowan 1993). In B. cereus $201 \mathrm{~g} \operatorname{lm} S$ cleavage reactions supplemented with $2.5 \mathrm{mM}$ EDTA, the presence of $\mathrm{Co}\left(\mathrm{NH}_{3}\right)_{6}{ }^{3+}$ at a minimum concentration of $\sim 1 \mathrm{mM}$ supports rate accelerations that are only modestly diminished relative to the enhancements obtained in the presence of saturating $\mathrm{Mg}^{2+}$ levels (Fig. 4B). The observation that this kinetically stable transition metal complex permits elevated rates of self-cleavage suggests that the $g \operatorname{lm} S$ ribozyme lacks a major catalytic or structural requirement for inner sphere divalent metal ion coordination. The relatively low concentrations of $\mathrm{Co}\left(\mathrm{NH}_{3}\right)_{6}{ }^{3+}$ required for robust activity, combined with the superstoichiometric amounts of EDTA in this range, argue against the participation of contaminating divalent metal ions.

We examined the effects of high monovalent ion concentrations to determine whether cationic species other than hydrated divalent metal ions or their structural mimics are capable of sustaining glmS ribozyme activity. To minimize the potential influence of contaminating levels of divalent metal ions, we included EDTA in these assays at a concentration of $25 \mathrm{mM}$. In the presence of molar concentrations of $\mathrm{KCl}$ (Fig. 4C), B. cereus $201 \mathrm{glmS}$ approaches enhancements of $\sim 10^{5}$-fold over the uncatalyzed rate of
RNA transesterification (Li and Breaker 1999), although these values are lower by $\sim 2$ orders of magnitude compared with the maximum $k_{\mathrm{obs}}$ in the presence of saturating divalent metal ions. The rate accelerations supported by molar concentrations of monovalent ions were unaffected when EDTA concentrations were increased to $100 \mathrm{mM}$ (data not shown), arguing against the possibility of divalent metal effects resulting from reduced chelation efficiency under high ionic strength conditions. The ability of monovalent ions at high concentrations to support substantial rate accelerations provides additional evidence that inner sphere metal ion coordination is not essential. Furthermore, our observations suggest the lack of a critical role for a divalent metal ion in any capacity in the active site, whether fully hydrated or chelated directly to the RNA.

The self-cleavage rates supported by monovalent ions alone are not accelerated optimally, however, and in this respect the $g \operatorname{lm} S$ ribozyme differs slightly from the hairpin and VS ribozymes, whose rate enhancements in molar concentrations of monovalent ions equal or exceed those achieved in the presence of divalent metal ions (Murray et al. 1998). Rather, the $g \operatorname{lm} S$ RNA behaves more similarly to the hammerhead ribozyme in this regard, which performs at rates reduced by $\sim 30$-fold when high concentrations of monovalent ions are provided as a substitute for $\mathrm{Mg}^{2+}$ (Murray et al. 1998; Curtis and Bartel 2001; O'Rear et al. 2001). The relatively modest effect of $\mathrm{Mg}^{2+}$ on $\mathrm{glmS}$ ribozyme rate enhancement also invites a comparison with the HDV ribozyme, in which the divalent metal ion contribution to the catalytic step is $\sim 25$-fold (Nakano et al. 2001).

These observations, together with the suboptimal rate accelerations supported by $\mathrm{Co}\left(\mathrm{NH}_{3}\right)_{6}{ }^{3+}$, suggest that not all roles of divalent metal ions in the $g l m S$ ribozyme cleavage mechanism may be performed equally by other cationic species. Perhaps the lower effectiveness of high concentrations of $\mathrm{KCl}$ compared with saturating levels of $\mathrm{Mg}^{2+}$ or $\mathrm{Co}\left(\mathrm{NH}_{3}\right)_{6}{ }^{3+}$ could result in part from less efficient structure stabilization due to the lower charge density of monovalent ions (Woodson 2005). Regardless, although divalent metal ions are critically important under conditions of physiological ionic strength, they appear not to be essential for $g l m S$ ribozyme catalysis. Instead, they are likely to fulfill roles such as electrostatic screening that may be compensated in large part by other cationic species. In summary, these data indicate that the $g \operatorname{lm} S$ ribozyme is mechanistically similar to the majority of other self-cleaving ribozymes, at least with regard to the absence of an indispensable catalytic or structural role for a divalent metal ion.

\section{Cleavage of phosphorothioate-modified substrate RNA by the $g / m S$ ribozyme}

The promotion of substantial $g l m S$ ribozyme function by an exchange-inert metal complex as well as by high monovalent ion concentrations suggested that any catalytic strategy involv- 
ing direct coordination of a divalent metal ion to the RNA is likely to be minor. Accordingly, catalytic strategies that utilize divalent metal ions as Lewis acids to facilitate deprotonation or to stabilize negative charge are not expected to be used by $\mathrm{glmS}$ ribozymes. To begin to assess this hypothesis, we examined the effect of thiophosphate substitutions at nonbridging phosphate oxygen atoms (NBPOs) of the cleavage site. Any effects on the rate constant for RNA cleavage resulting from these substitutions could be interpreted to reflect the reduced affinity for sulfur of hard metal ions (e.g., $\mathrm{Mg}^{2+}$ ), especially if the observed effects are rescued in the presence of a soft metal ion (e.g., $\mathrm{Mn}^{2+}$ ), which coordinates oxygen and sulfur ligands with similar affinities (Jaffe and Cohn 1979; Pecoraro et al. 1984).

Given our previous findings suggesting the absence of a major role for divalent metal ions in $g l m S$ ribozyme catalysis, we anticipated that any neutralization of developing negative charge that might occur at NBPOs would not involve direct metal ion coordination. Accordingly, we expected sulfur substitutions at these positions to have negligible effects on ribozyme function. To test this prediction, we first reconfigured the $g l m S$ ribozyme to form a bimolecular complex by splitting the $B$. cereus construct at $\mathrm{L} 1$, removing unpaired nucleotides in this region, and extending the P1 stem by 2 bp to strengthen the association of the resulting RNA fragments (Fig. 5A). The ability of the B. subtilis glmS ribozyme to function in this format has been demonstrated and is consistent with the lack of phylogenetic conservation among L1 sequences (Barrick et al. 2004).

Using chemical synthesis, two RNA "substrate" fragments were prepared that were identical in sequence but that contained at the cleavage site either a standard phosphate or a phosphate substituted with sulfur at one of the nonbridging positions. The modified substrate was synthesized as a diastereomeric mixture, with $R \mathrm{p}$ and $S \mathrm{p}$ sulfur substitutions expected to be present in approximately equal proportions (Burgers and Eckstein 1979). Such diastereomeric mixtures of phosphorothioate linkages at ribozyme cleavage sites have been used previously to establish whether various ribozymes and deoxyribozymes are sensitive to sulfur substitution at either NBPO (Breaker et al. 2003). For example, the hammerhead ribozyme is strongly inhibited by the $R \mathrm{p}$ sulfur substitution and expectedly was found to process a diastereomeric substrate to $\sim 50 \%$ completion in the presence of $\mathrm{Mg}^{2+}$, but to process nearly $100 \%$ of the mixed substrate when incubated with $\mathrm{Mn}^{2+}$. In contrast, other ribozymes and deoxyribozymes that do not exhibit a thio effect process mixed substrates nearly to completion with either $\mathrm{Mg}^{2+}$ or $\mathrm{Mn}^{2+}$ as the cofactor.

Under single-turnover conditions in reactions containing $10 \mathrm{mM} \mathrm{Mg}^{2+}$, the rate constant of $g \operatorname{lm} S$ ribozyme activity with the mixed thiophosphate substrate was approximately one-third of the rate constant with the unmodified substrate (Fig. 5B, left). Reactions performed in the same concentration of the more thiophilic $\mathrm{Mn}^{2+}$ ion displayed inhibition of mixed thiophosphate RNA cleavage to the same relative extent (Fig. $5 \mathrm{~B}$, right). The failure

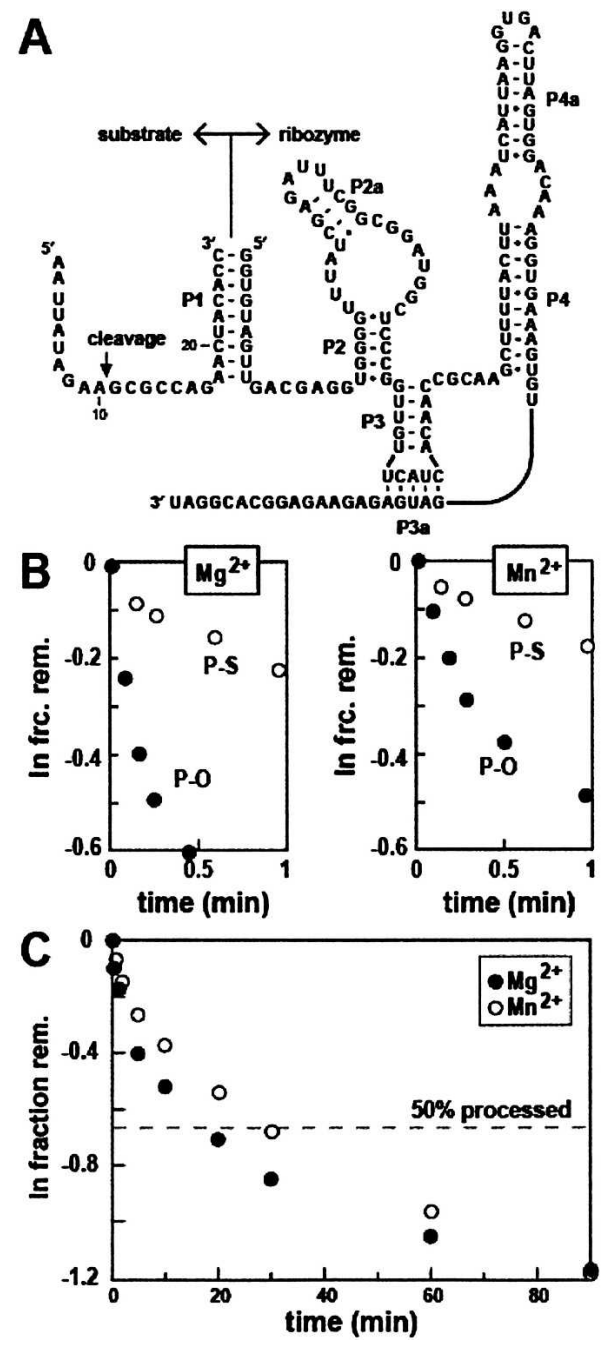

FIGURE 5. Absence of phosphorothioate effects at cleavage site nonbridging phosphate oxygens (NBPOs). (A) Secondary structure model of the bimolecular $\mathrm{glmS}$ ribozyme construct (based on B. cereus) used to assess effects of phosphorothioate modification at the cleavage site. (B) Time courses of ribozyme cleavage of unmodified ( $\mathrm{P}-\mathrm{O}$, filled circles) and phosphorothioate-modified (P-S, open circles) substrates in the presence of $10 \mathrm{mM} \mathrm{Mg}^{2+}$ or $10 \mathrm{mM} \mathrm{Mn}^{2+}$, respectively. Assays were performed in $2 \mathrm{mM}$ GlcN6P under single turnover conditions. Values were corrected for the fraction of substrate remaining uncleaved after exhaustive incubation. Approximate rate constants for initial phases of reactions in $\mathrm{Mg}^{2+}$ are $0.68 \mathrm{~min}^{-1}(\mathrm{P}-\mathrm{O})$ and $0.20 \mathrm{~min}^{-1}(\mathrm{P}-\mathrm{S})$; the corresponding values in $\mathrm{Mn}^{2+}$ are $0.40 \mathrm{~min}^{-1}$ $(\mathrm{P}-\mathrm{O})$ and $0.15 \mathrm{~min}^{-1}(\mathrm{P}-\mathrm{S})$. (C) Extended time courses of ribozyme cleavage of phosphorothioate-modified substrate molecules in the presence of $\mathrm{Mg}^{2+}$ or $\mathrm{Mn}^{2+}$ as indicated. Experimental conditions were as described in $B$, except that values were not corrected for the fraction of substrate remaining uncleaved after exhaustive incubation.

of $\mathrm{Mn}^{2+}$ to rescue the observed inhibitory effect of the sulfur substitutions suggests the limited importance of divalent metal ion coordination to a single cleavagesite NBPO in $g l m S$ ribozyme catalysis. Alterations in the geometry or charge distribution of the sulfur-substituted linkage might contribute to the modest rate reduction through 
adverse effects on active site conformation (Derrick et al. 2000). Alternatively, a specific interaction with an NBPO might be mediated by a functional group other than a metal ion.

Importantly, the yield of products resulting from thiophosphate-containing precursors substantially exceeds $50 \%$ at later time points in buffers containing $\mathrm{Mg}^{2+}$ as well as in ones containing $\mathrm{Mn}^{2+}$ (Fig. 5C). This argues against a profound impairment of catalysis resulting from the loss of a divalent metal contact with a specific thiophosphate isomer, since a catalytic requirement for such an interaction would result in the processing of only $\sim 50 \%$ of the mixed thiophosphate substrate in buffer containing $\mathrm{Mg}^{2+}$. This finding is consistent with our hypothesis that divalent metal ion coordination to a cleavage-site NBPO is not important for this ribozyme class.

The results obtained with phosphorothioate-modified substrates, together with the substantial rate enhancements observed in the absence of divalent metal ions, imply limited direct contributions of divalent metal ions to the chemical mechanism of the $g l m S$ ribozyme. The apparent lack of stringent divalent metal ion requirements may also be explained, however, by invoking a slow conformational rearrangement as the rate-limiting step, so that any large detrimental effects on chemical mechanism resulting from the absence of divalent metals would be masked. This scenario would require that the ribozyme catalyze the chemical step with a rate constant greatly exceeding the maximum $k_{\mathrm{obs}}$ value determined in our experiments. It is notable that the maximum rate constant for $g l m S$ ribozyme cleavage under optimized buffer conditions precisely matches that proposed for enzymes that fully employ two catalytic strategies for RNA cleavage: deprotonation of the nucleophilic 2'-hydroxyl group and establishment of a geometry for the linkage that is optimal for "in-line" nucleophilic attack (Breaker et al. 2003; Emilsson et al. 2003). Both the maximum rate constants and the kinetic characteristics of $g \operatorname{lm} S$ ribozymes from $B$. subtilis and B. cereus suggest that this ribozyme class has reached a speed limit that is common for RNA-cleaving ribozymes and deoxyribozymes that have been created by using in vitro evolution.

\section{Function of the P3/P4 domain}

It was previously determined that a truncated $g l m S$ ribozyme construct delimited at the $3^{\prime}$ end by the P2 element retains GlcN6P-dependent self-processing activity, albeit with some reduction in speed relative to the full length ribozyme (Winkler et al. 2004). The negative impact on ribozyme performance upon removal of the $\mathrm{P} 3 / \mathrm{P} 4$ domain was not unexpected, given the strong phylogenetic conservation of this substructure.

To define more precisely the contribution of the $\mathrm{P} 3 / \mathrm{P} 4$ domain to $g \operatorname{lm} S$ ribozyme catalysis, we examined the kinetic characteristics of a series of 3 '-end deletion constructs based on the ribozyme sequence from B. subtilis (Fig. 6A). We reasoned that two aspects of ribozyme function in which the $\mathrm{P} 3 / \mathrm{P} 4$ domain might be likely to participate are stabilization of the active conformation and recognition of the GlcN6P effector. To explore the former possibility, we monitored the rates of effector-induced self-cleavage of the $g \operatorname{lmS}$ RNA deletion series in varying concentrations of $\mathrm{Mg}^{2+}$ (Fig. 6B). The truncated RNA (P2 term), whose 3' terminus immediately follows the $\mathrm{P} 2$ secondary structure element, exhibits a marked difference in $\mathrm{Mg}^{2+}$-dependent activity when compared with a longer RNA (P3a term) that contains the entire $\mathrm{P} 3 / \mathrm{P} 4$ domain including the P3a pseudoknot. Specifically, P2 term exhibits a rate constant for self-cleavage in $1 \mathrm{mM} \mathrm{Mg}^{2+}$ that is $\sim 4$ orders of magnitude lower than that of P3a term under identical conditions. The rate constants for these variant RNAs converge at higher $\mathrm{Mg}^{2+}$ concentrations, however, such that the rate of the P2 term ribozyme variant is within 10-fold of the rate of the full-length RNA in reactions containing $100 \mathrm{mM} \mathrm{Mg}{ }^{2+}$. These findings indicate that the $\mathrm{P} 3 / \mathrm{P} 4$ domain permits optimal function of the $g l m S$ ribozyme at $\mathrm{Mg}^{2+}$ concentrations in the physiological range. Moreover, it appears that the deleterious effects resulting from the absence of this domain can be largely overcome by including high concentrations of $\mathrm{Mg}^{2+}$ in the reaction.

We explored the specific contribution of the P3a pseudoknot to ribozyme function by examining the activity of a
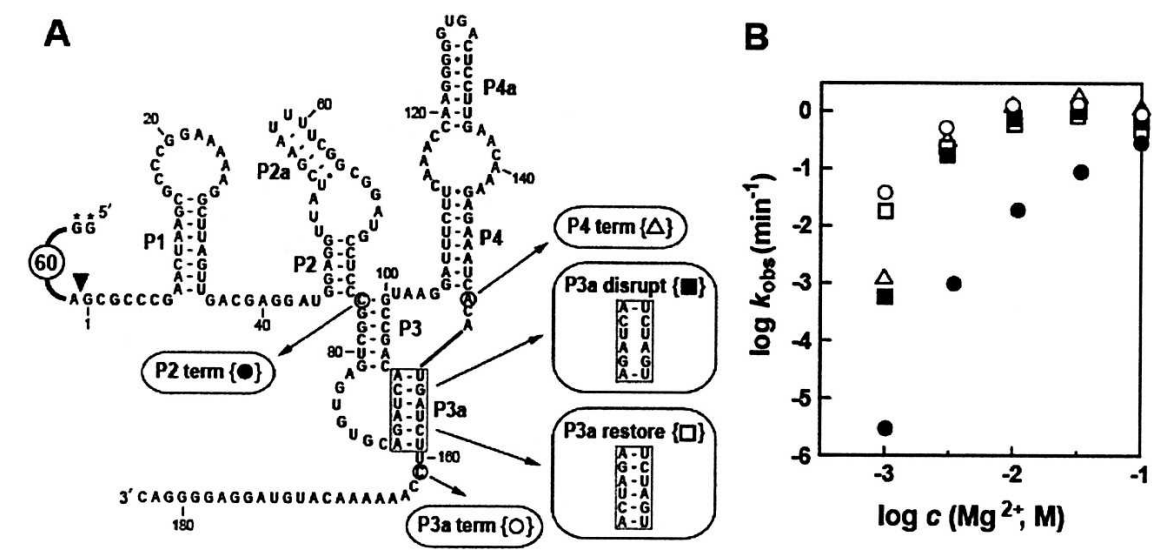

FIGURE 6. Altered $\mathrm{Mg}^{2+}$ dependence of $g l m S$ ribozyme constructs with $3^{\prime}$-end truncations. $(A)$ Secondary structure model of $B$. subtilis $246 \mathrm{glmS}$ RNA. Circled nucleotides correspond to the $3^{\prime}$ termini of individual truncated RNAs, whose names (P2 term, P4 term, P3a term) refer to the $3^{\prime}$ most stem element completely contained within the respective construct. Two additional engineered $g l m S$ ribozyme variants (each terminating at C183) individually disrupt and restore basepairing in the P3a pseudoknot (boxed). Bracketed symbols are used on the plot in $B$ to represent the $\mathrm{Mg}^{2+}$ dependence of the corresponding variants. Arrowhead indicates the cleavage site. The $\mathrm{G}$ residues marked by asterisks were introduced to facilitate transcription in vitro. (B) Effect of $\mathrm{Mg}^{2+}$ concentration on the cleavage rates of the $g \operatorname{lm} S$ ribozyme variants described in $A$. 
deletion variant that lacks only this element (P4 term) and by examining the activities of two variants of $\mathrm{P} 3 \mathrm{a}$ term that carry mutations in the pseudoknot (P3a disrupt and P3a restore) (Fig. 6A). The plot of the observed rate constants for P4 term largely overlaps that for P3a term over much of the $\mathrm{Mg}^{2+}$ concentration range (Fig. 6B). The effects of this truncation are manifested only in lower $\mathrm{Mg}^{2+}$ concentrations, with P4 term RNA exhibiting a rate constant that is slightly $>1$ order of magnitude lower than that of the fulllength ribozyme in $1 \mathrm{mM} \mathrm{Mg}^{2+}$. To confirm that this rate decrease in lower divalent metal ion concentrations results from the loss of the P3a base-pairing interaction, we constructed a mutant (P3a disrupt) in which the potential for the pseudoknot interaction is significantly attenuated. As expected, the P3a disrupt RNA exhibits a $\mathrm{Mg}^{2+}$-dependence profile similar to the one observed for $\mathrm{P} 4$ term. Moreover, a mutant containing compensatory changes that restore the proposed pseudoknot interaction responds similarly to the wild-type ribozyme (P3a term) over the full range of $\mathrm{Mg}^{2+}$ concentrations. These findings support the existence of the P3a pseudoknot and, furthermore, demonstrate that the integrity of this element is necessary to achieve optimal rate enhancement at $\mathrm{Mg}^{2+}$ levels in the physiological range. It is apparent, however, that function of the P3/P4 domain is not entirely contingent upon pseudoknot formation, since considerable rate accelerations are conferred by the P3/P4 domain even when the P3a pseudoknot interaction is disallowed. This analysis of pseudoknot function is consistent with a previous report on the contribution of this element to $g l m S$ ribozyme self-cleavage (Wilkinson and Been 2005).

We also considered the possibility that the $\mathrm{P} 3 / \mathrm{P} 4$ domain might contribute simultaneously to GlcN6P recognition. It was anticipated that any such effects mediated by the P3/P4 domain would likely be minor, since a truncated RNA lacking this domain was capable of attaining nearly wild-type rate enhancements without requiring an increase in the GlcN6P concentration beyond $200 \mu \mathrm{M}$ (Fig. 6B). Two different ribozyme constructs lacking the $\mathrm{P} 3 / \mathrm{P} 4$ domain, based on sequences from different organisms, were assayed over a range of GlcN6P concentrations. To facilitate rate constant determinations, the reaction kinetics of these truncated ribozymes were measured in buffers containing $100 \mathrm{mM} \mathrm{Mg}^{2+}$.

Both the P2 term glmS RNA derived from B. subtilis (Fig. $6 \mathrm{~A}$ ) and an analogous construct derived from $B$. cereus exhibited kinetic profiles that are nearly identical, with both attaining half-maximum rate enhancements in $\sim 200$ $\mu \mathrm{M}$ GlcN6P (Fig. 7A). The plots corresponding to the truncated ribozymes are highly similar to those of their full-length counterparts, which also achieve half-maximum rate acceleration in $\sim 200 \mu \mathrm{M}$ GlcN6P. As observed previously, the presence of $100 \mathrm{mM} \mathrm{Mg}^{2+}$ was not sufficient to compensate completely for the missing $\mathrm{P} 3 / \mathrm{P} 4$ domain, resulting in rate constants for the truncated RNAs that were uniformly reduced by approximately fivefold com-

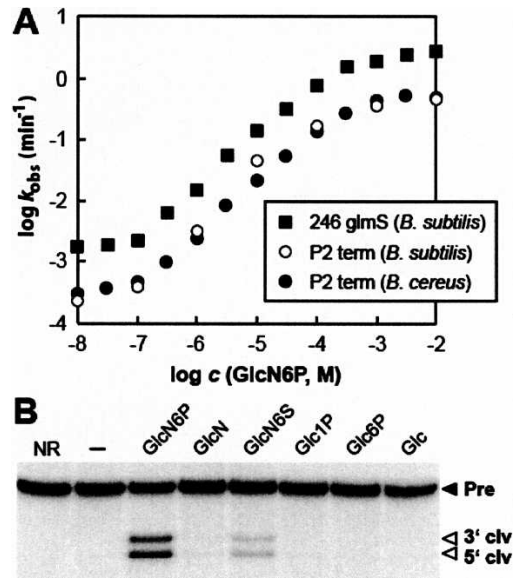

FIGURE 7. Effector-dependent activation of truncated $g l m S$ ribozymes. (A) GlcN6P concentration-dependent responses of minimal glmS ribozymes (terminating after the P2 stem) are similar to that of a full-length ribozyme. Data were obtained using the B. subtilis P2 term (Fig. 6A) (C76 3' terminus, open circles) and a B. cereus 201 $\mathrm{glmS}$-derived variant terminating at G68 (filled circles). Data corresponding to the full-length B. subtilis $246 \mathrm{glmS}$ ribozyme are shown for comparison (filled squares). Cleavage reactions included $100 \mathrm{mM}$ $\mathrm{MgCl}_{2}$. (B) Effector selectivity of a minimal $\mathrm{glmS}$ ribozyme. An internally ${ }^{32} \mathrm{P}$-labeled P2 term ribozyme from $B$. subtilis was incubated in the absence (-) or the presence of $200 \mu \mathrm{M}$ GlcN6P or related compound, as indicated. Reactions contained $100 \mathrm{mM} \mathrm{MgCl}$ and were halted after $5 \mathrm{~min}$ at room temperature. Precursor (Pre) and the $5^{\prime}\left(5^{\prime} \mathrm{Clv}\right)$ and $3^{\prime}\left(3^{\prime} \mathrm{Clv}\right)$ cleavage products are indicated. NR represents no reaction. Compounds are abbreviated as follows: $\mathrm{GlcN}$, glucosamine; GlcN6S, glucosamine 6-sulfate; Glc1P, glucose 1-phosphate; Glc6P, glucose 6-phosphate; Glc, glucose.

pared with full-length ribozyme rate constants under standard conditions.

The similarities in the responses to varying GlcN6P concentrations of the truncated and full-length RNAs suggest that the $\mathrm{P} 3 / \mathrm{P} 4$ domain does not participate directly in ligand-RNA complex formation. Moreover, the P2 term RNA from B. subtilis displays no obvious differences in the specificity of ligand recognition. The $\mathrm{P} 2$ term ribozyme is activated selectively by GlcN6P and, to a lesser extent, by glucosamine 6-sulfate, but not by other related compounds (Fig. 7B). This pattern of discrimination matches that reported for a full-length $g l m S$ RNA from B. subtilis (Winkler et al. 2004). Collectively, these data suggest that all of the molecular determinants employed by the glmS ribozyme in GlcN6P recognition are contained entirely within the P1/P2 core structure.

Taken together, the requirement of the $\mathrm{P} 3 / \mathrm{P} 4$ domain for maximum rate enhancement under low ionic strength conditions and its apparent lack of impact on effector recognition suggest that the primary role of this domain is to permit optimum catalytic function in physiological concentrations of $\mathrm{Mg}^{2+}$. The $\mathrm{P} 3 / \mathrm{P} 4$ structure thus seems to act as an auxiliary domain, probably by stabilizing the active conformation of the glmS ribozyme through tertiary interactions with the $\mathrm{P} 1 / \mathrm{P} 2$ core element. 


\section{DISCUSSION}

RNA enzymes generally rely on metal ions to adopt their catalytically active conformations. These cations participate in folding the RNA into a relatively compact globular structure by mediating packing of negatively charged phosphate groups through delocalized electrostatic shielding, and by stabilizing tertiary structures through more specific contacts with RNA functional groups (Hanna and Doudna 2000; Pyle 2002; Draper 2004). Furthermore, due to the limited intrinsic chemical functionality available to RNA enzymes, divalent cations provide a means by which the catalytic properties of RNA could be enhanced. For example, divalent metal ions could participate in chemical reactions as aqua complexes that promote general acid or general base catalysis (Fedor 2002; DeRose 2003). Indeed, ribonuclease $\mathrm{P}$ and the group I and II self-splicing introns display stringent divalent metal ion requirements (Pyle 2002). Similarly, the small self-cleaving ribozymes (hammerhead, hairpin, HDV, and Neurospora VS) were initially regarded as obligate metalloenzymes after early studies revealed strong dependencies on $\mathrm{Mg}^{2+}$ or certain other divalent cations (Dahm and Uhlenbeck 1991; Chowrira et al. 1993; Collins and Olive 1993; Suh et al. 1993).

In recent years, however, the degree to which divalent metal ions contribute to ribozyme function has been reevaluated, particularly in the cases of the small catalytic RNAs. A series of studies probing the metal ion requirements of the small self-cleaving ribozymes has revealed that divalent cations are not indispensable for catalysis, as they may be substituted quite effectively by high concentrations of monovalent ions, or in certain cases by exchange-inert metal hydrate mimics or organic polyamines (Hampel and Cowan 1997; Nesbitt et al. 1997; Young et al. 1997; Murray et al. 1998; Nakano et al. 2000; Curtis and Bartel 2001; O'Rear et al. 2001). One of the implications of these findings is that functional groups intrinsic to the RNA make significant and direct contributions to catalysis. Indeed, evidence to support direct nucleobase participation in catalysis has accrued from both biochemical and X-ray crystallographic analyses of several of the small, self-cleaving RNAs (Ferre-D'Amare et al. 1998; Perrotta et al. 1999; Nakano et al. 2000; Rupert and Ferre-D'Amare 2001; Lafontaine et al. 2002; Jones and Strobel 2003; Das and Piccirilli 2005; Kuzmin et al. 2005).

Representatives of the glmS class of self-cleaving ribozymes appear not to require direct involvement of divalent metal ions in the catalytic step of phosphoester transfer. Robust acceleration of self-cleavage in the presence of the exchange-inert metal hydrate mimic $\mathrm{Co}\left(\mathrm{NH}_{3}\right)_{6}{ }^{3+}$ supports the hypothesis that catalytic strategies employing inner sphere divalent metal ion coordination are not used by this ribozyme class. This conclusion is consistent with the absence of a substantial thio effect when a substrate containing cleavage site phosphorothioate substitutions is incubated with the ribozyme in the presence of $\mathrm{Mg}^{2+}$. Similarly to several other self-cleaving ribozymes, the $g \operatorname{lm} S$ motif exhibits substantial rate enhancements in elevated concentrations of monovalent ions alone, supporting the absence of a requirement even for specific outer sphere divalent metal contacts. Thus, while it is likely that divalent metal ions fulfill important structural roles under conditions of physiological ionic strength, it appears that they do not make significant, direct contributions to glmS ribozyme-mediated catalysis.

The apparent absence of catalytic roles for divalent metal ions in the $g \operatorname{lm} S$ ribozyme cleavage mechanism suggests the involvement of functional groups of the ribozyme itself or, perhaps, of the metabolite serving as the ribozyme activator. In the latter case, GlcN6P could serve as a coenzyme, with its amine group participating in a cleavage mechanism that involves proton transfer. Rate enhancements measured in the absence of GlcN6P are substantially elevated by Tris buffer, which is an imperfect structural mimic of a portion of GlcN6P. Additional studies with other analogs of GlcN6P (Winkler et al. 2004) or Tris (McCarthy et al. 2005) suggest that the amine group is essential for ligand-mediated rate enhancement of the $g l m S$ ribozyme.

The presence of GlcN6P stimulates the activity of the glmS ribozyme by $\sim 100,000$-fold compared with the nonactivated rate constant (measured using buffering compounds other than Tris). If GlcN6P serves as an allosteric effector and not as a coenzyme, this high level of ribozyme activation would demand remarkably tight control of $\mathrm{glmS}$ ribozyme conformation by the metabolite. Such an exquisite degree of allosteric modulation of ribozyme function by a small molecule would be unprecedented among metabolite-responsive allosteric ribozymes that have been engineered or selected in vitro (Silverman 2003), and thus would argue against an allosteric effector function for GlcN6P.

In this study we also demonstrate that $g \operatorname{lm} S$ RNA constructs from B. subtilis and B. cereus that lack a complete P3/ P4 domain retain GlcN6P-dependent ribozyme activity, although these constructs require higher $\mathrm{Mg}^{2+}$ concentrations for full activity. These results, together with the apparent lack of involvement of the P3/P4 domain in GlcN6P recognition, indicate that the $\mathrm{P} 3 / \mathrm{P} 4$ domain serves primarily to permit optimum rate enhancement of the $g l m S$ ribozyme at physiological $\mathrm{Mg}^{2+}$ concentrations. In fulfilling this role, the P3/P4 substructure may act as an auxiliary domain, peripheral to the catalytic core, which stabilizes the active ribozyme conformation through tertiary interactions with the P1/P2 domain.

It is worth noting that the internal loop within the P4 stem of the glmS ribozyme contains several highly conserved, consecutive adenosine residues, which potentially could mediate helix packing through minor groove tertiary interactions in the manner described previously for the P4P6 domain of the Tetrahymena group I intron and other 
ribozymes (Doherty et al. 2001). Interestingly, the deviation from the consensus secondary structure model observed in the P3/P4 domain of the glmS ribozyme from $D$. radiodurans (Fig. 1) is consistent with the proposed involvement of this domain in stabilization of the catalytic core rather than in the reaction mechanism itself or in GlcN6P recognition. Presumably, there is a diversity of structural approaches by which an auxiliary domain may stabilize the active conformation of the $g \operatorname{lm} S$ ribozyme catalytic core. The P1/P2 core domain itself, however, because it contains the bulk of both the catalytic and ligand recognition determinants, is probably subject to more stringent sequence constraints. Although the glmS ribozyme from D. radiodurans is the only example of this motif yet uncovered in which significant changes exist in the auxiliary $\mathrm{P} 3 / \mathrm{P} 4$ domain, analogous observations have been made with other RNA enzymes. In the Tetrahymena group I intron, for example, the P5abc peripheral element, which is significantly less conserved than the catalytic core (Michel and Westhof 1990), participates in stabilizing the active structure of the ribozyme (Doherty et al. 1999; Engelhardt et al. 2000).

The use of auxiliary stabilizing domains appears to be widespread among natural ribozymes, with several examples of these elements having recently been described among the small self-cleaving RNAs. The hammerhead ribozyme is constructed essentially as a three-way helical junction, and in its minimized form appears to fold in a stepwise manner (Bassi et al. 1997; Hammann et al. 2001). Dissection of this folding pathway in vitro has revealed that the first structural transition occurs at $\sim 500 \mu \mathrm{M} \mathrm{Mg}^{2+}$, when helices II and III are observed to stack coaxially. A subsequent reorganization, in which the catalytic core adopts its active conformation concomitantly with the rotation of helix I into apposition with helix II, requires a concentration of $\mathrm{Mg}^{2+}$ in excess of the physiological range. Recently, it has been demonstrated that hammerhead ribozymes in their natural context contain terminal or internal loops on helices I and II that drastically reduce the functional requirement for $\mathrm{Mg}^{2+}$ (De la Pena et al. 2003; Khvorova et al. 2003), thereby resolving the discrepancy between the high divalent metal ion concentrations required for cleavage activity of the minimal motif in vitro and the considerably lower estimated concentrations of free $\mathrm{Mg}^{2+}$ in the cellular environment (Romani and Scarpa 1992). These auxiliary loops, which exhibit a lesser degree of phylogenetic conservation than the catalytic core, appear to associate with one another through tertiary contacts to facilitate folding of the active structure (Penedo et al. 2004). Ostensibly, these enhancing effects on folding are elicited by restricting the conformational freedom of the relevant helices, thereby channeling the folding pathway toward intermediates that approximate the active geometry of the hammerhead ribozyme (De la Pena et al. 2003; Khvorova et al. 2003; Lilley 2003; Penedo et al. 2004). Moreover, by obviating the requirement for high $\mathrm{Mg}^{2+}$ concentrations in the structural transition to the active fold, the auxiliary domains in helices I and II permit efficient function of the hammerhead ribozyme in vivo.

Another example of a nucleolytic RNA benefiting from auxiliary structural elements is provided by the hairpin ribozyme. This ribozyme occurs naturally in the context of a four-way helical junction, although the minimum catalytically competent motif requires only two of these helices, each containing conserved loop domains that interact to form the active center (Ferre-D'Amare 2004). In the minimized version, the two helices are hinged at the junction point to allow association of the loop domains, and folding of this form requires significantly higher $\mathrm{Mg}^{2+}$ concentrations as compared with the native form (Walter et al. 1999; Zhao et al. 2000). Thus, the interdomain junction of the hairpin ribozyme, which is remote from the catalytic core, nevertheless exerts a profound influence on the folding of this motif. Single-molecule fluorescence studies have offered a mechanism for this effect by demonstrating that the structural dynamics of the natural, fourway junction form predispose hairpin RNAs toward the population of a discrete structural intermediate in which the loop domains are poised to interact (Tan et al. 2003).

It is evident that, apart from its regulation by GlcN6P, the $g \operatorname{lm} S$ ribozyme appears to be similar in many respects to some of the other small phosphoryl transfer ribozymes. In addition to exhibiting no stringent requirement for divalent metal ion participation in catalysis, the glmS RNA relies on a supplemental structural domain that, while it is not essential to the reaction mechanism, nonetheless is required for efficient function under physiological conditions. Accordingly, this self-cleaving RNA motif underscores the critical contribution to ribozyme function of structural elements peripheral to the catalytic core.

\section{MATERIALS AND METHODS}

\section{Chemicals and oligonucleotides}

D-glucosamine 6-phosphate, D-glucosamine, D-glucosamine 6sulfate, $\beta$-D-glucose 1-phosphate, D-glucose 6-phosphate, and D-glucose were purchased from Sigma. Synthetic DNA oligonucleotides prepared using standard solid-phase methods were provided by the HHMI Biopolymer/Keck Foundation Biotechnology Resource Laboratory and were purified by denaturing ( $8 \mathrm{M}$ urea) polyacrylamide gel electrophoresis (PAGE). Synthetic RNA oligonucleotides with chemical modifications at the cleavage site were purchased from Dharmacon RNA Technologies.

\section{Construction of ribozyme templates}

Templates encoding full-length $g \operatorname{lm} S$ ribozymes and variants with $5^{\prime}$ or $3^{\prime}$-end truncations were amplified from plasmid clones by PCR using appropriate primers. Plasmids were created with a TOPO TA 
Cloning Kit (Invitrogen) according to the manufacturer's instructions, using PCR-amplified fragments corresponding to the $g \operatorname{lmS}$ ribozyme-containing IGRs from B. cereus (ATCC 10987) and $B$. subtilis (strain 1A40). The template for the version of the B. subtilis $g l m S$ ribozyme containing a disrupted P3a stem (Fig. 5A) was generated by PCR as described above using a reverse primer bearing the appropriate point mutations. The DNA encoding the double mutant ribozyme, in which compensatory mutations restored base-pairing in the P3a stem, was prepared in the same manner except that the template for the PCR was not a plasmid but rather double-stranded DNA prepared by extending the two partially complementary oligonucleotides, 5'-CTTATTTTCTCAATAGGAAAAGAAGACGGGAT TATTGCTTTACCTATAATTATAGCGCCCGAACTAAGCGCCCG GAAAAAGGCTTAGTTGACGAGGATGGAGGTTATCGA and 5'TGTGATTTCTCTTTGTTCAAGGAGTCACCCCCTTGGTTTGAA GAAATCCTTACGGCTGTCTAGTGCACACTCAGCCGGGAGGC ATCCGCCGAAAATTCGATAACCTCCATCCT, with SuperScript II reverse transcriptase (Invitrogen) according to the manufacturer's instructions.

\section{RNA preparations}

Transcriptions in vitro were performed either with a RiboMAX Large Scale RNA Production System-T7 (Promega) according to the manufacturer's instructions or in a $50-\mu \mathrm{L}$ volume, incubated $2 \mathrm{~h}$ at $37^{\circ} \mathrm{C}$, containing $50 \mathrm{mM}$ Tris- $\mathrm{HCl}\left(\mathrm{pH} 7.5\right.$ at $\left.23^{\circ} \mathrm{C}\right), 15 \mathrm{mM}$ $\mathrm{MgCl}_{2}, 5 \mathrm{mM}$ dithiothreitol (DTT), $2 \mathrm{mM}$ spermidine, $2.5 \mathrm{mM}$ each of the four ribonucleoside $5^{\prime}$ triphosphates (NTPs), $1 \mu \mathrm{M}$ doublestranded template DNA, and $5 \mathrm{U} / \mu \mathrm{L}$ T7 RNA polymerase (T7 RNAP). Transcriptions in vitro of internally radiolabeled ribozymes also contained $10 \mu \mathrm{Ci}\left[\alpha-{ }^{32} \mathrm{P}\right] \mathrm{UTP}$. Note that, due to the apparent stimulatory effect of Tris on $\mathrm{glmS}$ ribozyme catalysis (Fig. 3B, inset), lower yields of unreacted RNA should be expected from transcriptions utilizing this buffer. RNAs were purified using denaturing ( $8 \mathrm{M}$ urea) polyacrylamide gel electrophoresis (PAGE) and eluted from gel slices in 10 mM Tris- $\mathrm{HCl}$ ( $\mathrm{pH}$ 7.5), $200 \mathrm{mM} \mathrm{NaCl}, 1 \mathrm{mM}$ EDTA. Recovered material was concentrated by precipitation with ethanol. Enzymatically synthesized RNA molecules that were to be $5^{\prime}{ }^{32} \mathrm{P}$ labeled were first dephosphorylated with alkaline phosphatase (Roche Diagnostics) and then radiolabeled using $\gamma-{ }^{32} \mathrm{P}$ [ATP] and T4 polynucleotide kinase (New England Biolabs) according to the manufacturers' instructions. Subsequent purification by denaturing PAGE was performed as described above.

\section{Ribozyme assays}

Rate constants for ribozyme-mediated strand cleavage were measured by incubating trace amounts of radiolabeled RNA at $23^{\circ} \mathrm{C}$ under standard conditions $\left(50 \mathrm{mM}\right.$ Tris- $\mathrm{HCl}\left[\mathrm{pH} 7.5\right.$ at $23^{\circ} \mathrm{C}$, $200 \mathrm{mM} \mathrm{KCl}, 10 \mathrm{mM} \mathrm{MgCl} 2,200 \mu \mathrm{M}$ GlcN6P) or as otherwise indicated. Assays of cleavage in trans of the phosphorothioatemodified RNA included $\sim 5 \mathrm{nM} \mathrm{5}{ }^{\prime 32}$ P-labeled "substrate" and 200 nM "ribozyme" (Fig. 5). Reactions were terminated at appropriate times with either an equal volume of urea-containing gel loading buffer ( $87 \mathrm{mM}$ Tris base, $89 \mathrm{mM}$ boric acid, $20 \%$ sucrose, $0.05 \%$ bromophenol blue, $0.05 \%$ xylene cyanol, $0.1 \%$ sodium dodecyl sulfate, $7.3 \mathrm{M}$ urea, $100 \mathrm{mM}$ EDTA) or three volumes of a formamide-based loading buffer (95\% formamide, $10 \mathrm{mM}$ EDTA, $0.1 \%$ bromophenol blue, $0.1 \%$ xylene cyanol). Reaction products were separated by denaturing PAGE, and radiolabeled species were analyzed using a PhosphorImager and ImageQuant software (Molecular Dynamics). Rate constants $\left(k_{\mathrm{obs}}\right)$ were determined assuming first order reaction kinetics using data points from the first $10 \%-$ $30 \%$ of the reaction and were derived from the slope of the line obtained by plotting the natural logarithm of the fraction of precursor RNA remaining versus time. Final extents of fast self-cleavage reactions typically ranged from $70 \%-90 \%$, and were not observed to change significantly as a function of cation concentrations or $\mathrm{pH}$ conditions. For cleavage reactions in trans, significant deviations from linearity were observed even after correcting for the uncleaved fraction, suggesting that the use of chemically synthesized substrates may result in diverse cleavage efficiencies.

\section{ACKNOWLEDGMENTS}

We thank members of the Breaker laboratory for helpful discussions. This work was supported by grants from the NIH and the NSF.

Received October 18, 2005; accepted January 4, 2006.

\section{REFERENCES}

Barrick, J.E., Corbino, K.A., Winkler, W.C., Nahvi, A., Mandal, M., Collins, J., Lee, M., Roth, A., Sudarsan, N., Jona, I., et al. 2004. New RNA motifs suggest an expanded scope for riboswitches in bacterial genetic control. Proc. Natl. Acad. Sci. 101: 6421-6426.

Bassi, G.S., Murchie, A.I., Walter, F., Clegg, R.M., and Lilley, D.M. 1997. Ion-induced folding of the hammerhead ribozyme: A

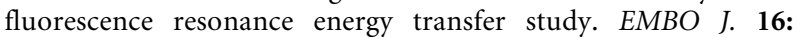
7481-7489.

Breaker, R.R., Emilsson, G.M., Lazarev, D., Nakamura, S., Puskarz, I.J., Roth, A., and Sudarsan, N. 2003. A common speed limit for RNAcleaving ribozymes and deoxyribozymes. RNA 9: 949-957.

Burgers, P.M.J. and Eckstein, F. 1979. Diastereomers of 5' O-adenosyl 3'-O-uridyl phosphorothioate: Chemical synthesis and enzymatic properties. Biochemistry 18: 592-596.

Chowrira, B.M., Berzal-Herranz, A., and Burke, J.M. 1993. Ionic requirements for RNA binding, cleavage, and ligation by the hairpin ribozyme. Biochemistry 32: 1088-1095.

Collins, R.A. and Olive, J.E. 1993. Reaction conditions and kinetics of self-cleavage of a ribozyme derived from Neurospora VS RNA. Biochemistry 32: 2795-2799.

Corbino, K.A., Barrick, J.E., Lim, J., Welz, R., Tucker, B.J., Puskarz, I., Mandal, M., Rudnick, N.D., and Breaker, R.R. 2005. Evidence for a second class of S-adenosylmethionine riboswitches and other regulatory RNA motifs in alpha-proteobacteria. Genome Biol. 6: R70.

Cowan, J.A. 1993. Metallobiochemistry of RNA. $\mathrm{Co}\left(\mathrm{NH}_{3}\right)_{6}{ }^{3+}$ as a probe for $\mathrm{Mg}^{2+}$ (aq) binding sites. J. Inorg. Biochem. 49: 171-175.

Curtis, E.A. and Bartel, D.P. 2001. The hammerhead cleavage reaction in monovalent cations. RNA 7: 546-552.

Dahm, S.C. and Uhlenbeck, O.C. 1991. Role of divalent metal ions in the hammerhead RNA cleavage reaction. Biochemistry 30: 9464-9469.

Das, S.R. and Piccirilli, J.A. 2005. General acid catalysis by the hepatitis delta virus ribozyme. Nat. Chem. Biol. 1: 45-52.

De la Pena, M., Gago, S., and Flores, R. 2003. Peripheral regions of natural hammerhead ribozymes greatly increase their self-cleavage activity. EMBO J. 22: 5561-5570.

DeRose, V.J. 2003. Metal ion binding to catalytic RNA molecules. Curr. Opin. Struct. Biol. 13: 317-324.

Derrick, W.B., Greef, C.H., Caruthers, M.H., and Uhlenbeck, O.C. 2000. Hammerhead cleavage of the phosphorodithioate linkage. Biochemistry 39: 4947-4954. 
Doherty, E.A., Herschlag, D., and Doudna, J.A. 1999. Assembly of an exceptionally stable RNA tertiary interface in a group I ribozyme. Biochemistry 38: 2982-2990.

Doherty, E.A., Batey, R.T., Masquida, B., and Doudna, J.A. 2001. A universal mode of helix packing in RNA. Nat. Struct. Biol. 8: 339-343.

Draper, D.E. 2004. A guide to ions and RNA structure. RNA 10: 335-343.

Emilsson, G.M., Nakamura, S., Roth, A., and Breaker, R.R. 2003. Ribozyme speed limits. RNA 9: 907-918.

Engelhardt, M.A., Doherty, E.A., Knitt, D.S., Doudna, J.A., and Herschlag, D. 2000. The P5abc peripheral element facilitates preorganization of the Tetrahymena group I ribozyme for catalysis. Biochemistry 39: 2639-2651.

Fedor, M.J. 2002. The role of metal ions in RNA catalysis. Curr. Opin. Struct. Biol. 12: 289-295.

Fedor, M.J. and Williamson, J.R. 2005. The catalytic diversity of RNAs. Nat. Rev. Mol. Cell. Biol. 6: 399-412.

Ferre-D’Amare, A.R. 2004. The hairpin ribozyme. Biopolymers 73: 7178

Ferre-D’Amare, A.R., Zhou, K., and Doudna, J.A. 1998. Crystal structure of a hepatitis delta virus ribozyme. Nature 395: 567-574.

Hammann, C., Norman, D.G., and Lilley, D.M. 2001. Dissection of the ion-induced folding of the hammerhead ribozyme using ${ }^{19} \mathrm{~F}$ NMR. Proc. Natl. Acad. Sci. 98: 5503-5508.

Hampel, A. and Cowan, J.A. 1997. A unique mechanism for RNA catalysis: The role of metal cofactors in hairpin ribozyme cleavage. Chem. Biol. 4: 513-517.

Hanna, R. and Doudna, J.A. 2000. Metal ions in ribozyme folding and catalysis. Curr. Opin. Chem. Biol. 4: 166-170.

Jaffe, E.K. and Cohn, M. 1979. Diastereomers of the nucleoside phosphorothioates as probes of the structure of metal nucleotide substrates and of the nucleotide binding site of yeast hexokinase. $J$. Biol. Chem. 254: 10839-10845.

Jones, F.D. and Strobel, S.A. 2003. Ionization of a critical adenosine residue in the neurospora Varkud Satellite ribozyme active site. Biochemistry 42: 4265-4276.

Jou, R. and Cowan, J.A. 1991. Ribonuclease H activation by inert transition-metal complexes. Mechanistic probes for metallocofactors: Insights on the metallobiochemistry of divalent magnesium ion. J. Am. Chem. Soc. 113: 6685-6686.

Khvorova, A., Lescoute, A., Westhof, E., and Jayasena, S.D. 2003. Sequence elements outside the hammerhead ribozyme catalytic core enable intracellular activity. Nat. Struct. Biol. 10: 708-712.

Kushner, S.R. 2002. mRNA decay in Escherichia coli comes of age. J. Bacteriol. 184: 4658-4665.

Kuzmin, Y.I., Da Costa, C.P., Cottrell, J.W. and Fedor, M.J. 2005. Role of an active site adenine in hairpin ribozyme catalysis. J. Mol. Biol. 349: 989-1010.

Lafontaine, D.A., Wilson, T.J., Zhao, Z.Y., and Lilley, D.M. 2002. Functional group requirements in the probable active site of the VS ribozyme. J. Mol. Biol. 323: 23-34.

Li, Y. and Breaker, R.R. 1999. Kinetics of RNA degradation by specific base catalysis of transesterification involving the 2'-hydroxyl group. J. Am. Chem. Soc. 121: 5364-5372.

Lilley, D.M.J. 2003. Ribozymes—a snip too far? Nat. Struct. Biol. 10: 672-673.

Macke, T.J., Ecker, D.J., Gutell, R.R., Gautheret, D., Case, D.A., and Sampath, R. 2001. RNAMotif, an RNA secondary structure definition and search algorithm. Nucleic Acids Res. 29: 4724-4735.

Mandal, M. and Breaker, R.R. 2004. Gene regulation by riboswitches. Nat. Rev. Mol. Cell Biol. 5: 451-463.

McCarthy, T.J., Plog, M.A., Floy, S.A., Jansen, J.A., Soukup, J.K., and Soukup, G.A. 2005. Ligand requirements for $g \operatorname{lmS}$ ribozyme selfcleavage. Chem. Biol. 12: 1221-1226.

Michel, F. and Westhof, E. 1990. Modelling of the three-dimensional architecture of group I catalytic introns based on comparative sequence analysis. J. Mol. Biol. 216: 585-610.

Murray, J.B., Seyhan, A.A., Walter, N.G., Burke, J.M., and Scott, W.G. 1998. The hammerhead, hairpin and VS ribozymes are catalytically proficient in monovalent cations alone. Chem. Biol. 5: 587-595.

Nakano, S., Chadalavada, D.M., and Bevilacqua, P.C. 2000. General acid-base catalysis in the mechanism of a hepatitis delta virus ribozyme. Science 287: 1493-1497.

Nakano, S., Proctor, D.J., and Bevilacqua, P.C. 2001. Mechanistic characterization of the HDV genomic ribozyme: Assessing the catalytic and structural contributions of divalent metal ions within a multichannel reaction mechanism. Biochemistry 40: 1202212038.

Nesbitt, S., Hegg, L.A., and Fedor, M.J. 1997. An unusual pH-independent and metal-ion-independent mechanism for hairpin ribozyme catalysis. Chem. Biol. 4: 619-630.

O'Rear, J.L., Wang, S., Feig, A.L., Beigelman, L., Uhlenbeck, O.C., and Herschlag, D. 2001. Comparison of the hammerhead cleavage reactions stimulated by monovalent and divalent cations. RNA 7: $537-545$.

Pecoraro, V.L., Hermes, J.D., and Cleland, W.W. 1984. Stability constants of $\mathrm{Mg}^{2+}$ and $\mathrm{Cd}^{2+}$ complexes of adenine nucleotides and thionucleotides and rate constants for formation and dissociation of MgATP and MgADP. Biochemistry 23: 52625271.

Penedo, J.C., Wilson, T.J., Jayasena, S.D., Khvorova, A., and Lilley, D.M.J. 2004. Folding of the natural hammerhead ribozyme is enhanced by interaction of auxiliary elements. RNA 10: 880888.

Perrotta, A.T., Shih, I., and Been, M.D. 1999. Imidazole rescue of a cytosine mutation in a self-cleaving ribozyme. Science 286: 123126.

Pyle, A.M. 2002. Metal ions in the structure and function of RNA. J. Biol. Inorg. Chem. 7: 679-690.

Romani, A. and Scarpa, A. 1992. Regulation of cell magnesium. Arch. Biochem. Biophys. 298: 1-12.

Rupert, P.B. and Ferre-D'Amare, A.R. 2001. Crystal structure of a hairpin ribozyme-inhibitor complex with implications for catalysis. Nature 410: 780-786.

Silverman, S.K. 2003. Rube Goldberg goes (ribo)nuclear? Molecular switches and sensors made from RNA. RNA 9: 377-383.

Soukup, J.K. and Soukup, G.A. 2004. Riboswitches exert genetic control through metabolite-induced conformational change. Curr. Opin. Struct. Biol. 14: 344-349.

Suh, Y.-A., Kumar, P.K.R., Taira, K., and Nishikawa, S. 1993. Selfcleavage activity of the genomic HDV ribozyme in the presence of various divalent metal ions. Nucleic Acids Res. 21: 3277-3280.

Tan, E., Wilson, T.J., Nahas, M.K., Clegg, R.M., Lilley, D.M.J., and Ha, T. 2003. A four-way junction accelerates hairpin ribozyme folding via a discrete intermediate. Proc. Natl. Acad. Sci. 100: 9308-9313.

Walter, N.G., Burke, J.M., and Millar, D.P. 1999. Stability of hairpin ribozyme tertiary structure is governed by the interdomain junction. Nat. Struct. Biol. 6: 544-549.

Wilkinson, S.R. and Been, M.D. 2005. A pseudoknot in the $3^{\prime}$ noncore region of the $g \operatorname{lm} S$ ribozyme enhances self-cleavage activity. RNA 11: 1788-1794.

Winkler, W.C. 2005. Metabolic monitoring by bacterial mRNAs. Arch. Microbiol. 183: 151-159.

Winkler, W.C., Nahvi, A., Roth, A., Collins, J.A., and Breaker, R.R. 2004. Control of gene expression by a natural metabolite-responsive ribozyme. Nature 428: 281-286.

Woodson, S.A. 2005. Metal ions and RNA folding: A highly charged topic with a dynamic future. Curr. Opin. Chem. Biol. 9: $104-109$.

Young, K.J., Gill, F., and Grasby, J.A. 1997. Metal ions play a passive role in the hairpin ribozyme catalysed reaction. Nucleic Acids Res. 25: 3760-3766.

Zhao, Z.-Y., Wilson, T.J., Maxwell, K., and Lilley, D.M.J. 2000. The folding of the hairpin ribozyme: Dependence on the loops and the junction. RNA 6: 1833-1846. 

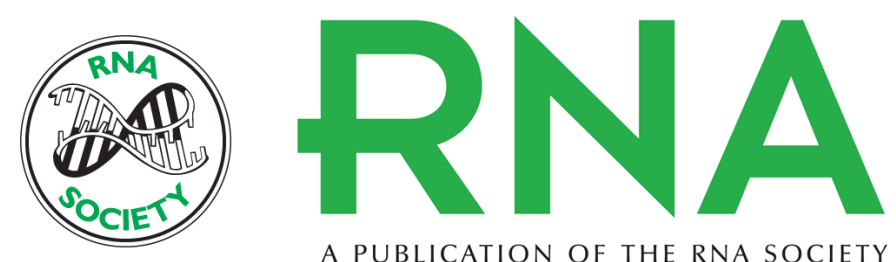

A PUBLICATION OF THE RNA SOCIETY

\section{Characteristics of the glmS ribozyme suggest only structural roles for divalent metal ions}

ADAM ROTH, ALI NAHVI, MARK LEE, et al.

RNA 2006 12: 607-619

References This article cites 61 articles, 18 of which can be accessed free at:

http://rnajournal.cshlp.org/content/12/4/607.full.html\#ref-list-1

\section{License}

Email Alerting Receive free email alerts when new articles cite this article - sign up in the box at the Service top right corner of the article or click here.

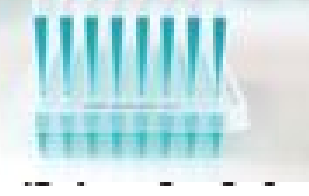

